\title{
STATUS AND MANAGEMENT OF SENGGARINGAN FISH (MYSTUS SINGARINGAN) AS FISHERIES RESOURCES: A CASE STUDY AT THE KLAWING RIVER, PURBALINGGA DISTRICT, CENTRAL JAVA OF INDONESIA
}

\author{
Pramono Taufik Budhi ${ }^{*}$ \\ Faculty of Fisheries and Marine Sciences, University of Jenderal Soedirman, Purwokerto, \\ Indonesia
}

Arfiati Diana, Widodo Maheno Sri, Yanuhar Uun

Faculty of Fisheries and Marine Science, University of Brawijaya, Malang, Indonesia

*E-mail: tb1pram@yahoo.com

\begin{abstract}
This study aims to find out the status and management of Senggaringan fish as resources in the Klawing River, Purbalingga District, Central Java, Indonesia. Research method employed was in-depth interview method using open questionnaires related to the use of aquatic and fish resources. The results have showed that there was a conflict of interest in the utilization and management of the Klawing River by various parties including farmers, fishermen, industry, and local/central government. Conflicts of interests that are not managed properly are a threat to existing aquatic ecosystems and fish resources. Senggaringan fish has potential of benefits for the surrounding community, both for the economic benefit and nutrients benefit. However, senggaringan fish are often exploited by unsustainable and environmentally unfriendly consumption. Various activities on the Klawing River are thought to cause water conditions and the senggaringan fish population to deteriorate. Considering the status and the potential of senggaringan fish, various co-management efforts, monitoring water quality, fishing method at regular intervals, restocking, and domestication need to be done.
\end{abstract}

\section{KEY WORDS}

Mystus singaringan, Klawing river, management, water.

The Klawing River is one of the tributaries of the Serayu River located in Purbalingga District, Central Java Province, Indonesia. The Klawing River reaches $55.5 \mathrm{~km}$ in length, the width reaches $15.6-47.3 \mathrm{~m}$ and the depth is 0.65-2.16 $\mathrm{m}$ (Suryaningsih et al., 2018). Currently, the Klawing River is undergoing functional changes for various activities, such as agriculture, fisheries, tourism, mining, and industry. Agricultural activities are facilitated by the construction of dam in Slinga Village, which is located near the middle part of the Klawing River, in 2010-2012 to irrigate 6696-hectare paddy fields. In addition, sand and stone mining activities, traditionally and modernly, are increasingly intensive using sand suction pumps. Other various types of industries have also established in the downstream along the river. Fishing activities have become more intensive as well.

Activities that utilize river waters certainly have a negative impact, directly or indirectly, on the aquatic ecosystems and fish diversity (Fithra and Siregar, 2010; Samitra and Rozi, 2018). In the meantime, ichthyofauna diversity in the Klawing River is still very limited. Suryaningsih et.al (2018) have reported that from upstream to downstream area, there are 18 species and 11 families in the Klawing River. Whereas, Pramono et al. (2018) have reported that there are 13 species, 7 families, and 13 genus in the downstream area of the Klawing River. Moreover, species found are invasive alien species, such as gourami (Osphronemus gouramy), suckermouth catfish (Hypostomus plecostomus) (Pramono et al., 2018), tilapia (Oreochromis mosambicus, Oreochromis niloticus), and guppy (Poecilia reticulata) (Suryaningsih et.al, 2018). This scientific information is a database of diversity of fish resources in the Klawing River. 
One of fish species that has economic value in the Klawing River is senggaringan fish (Mystus singaringan) from Bagridae family (Pramono et al., 2018). Senggaringan fish catch (Mystus singaringan) in the Klawing River has been recorded since 2012 to 2016, reaching 98.56 tons (38.80\%) of the total catch of 254 tons (Fisheries and Food Security Agency of Purbalingga Regency, 2018). However, based on the interview with fishermen, senggaringan fish is currently very difficult to catch in the Klawing River. The consumption of fish from the genus Mystus, from small to large size, also occurs in several places, such as the consumption of Mystus Cavasius in India (Garg et al., 2013) and Mystus Bleekeri (Naeem and Ishtiaq, 2011; Naeem et al., 2012), Mystus tengra, and Mystus Cavasius in Pakistan (Akhter et al., 2017). The ongoing fishing activity of senggaringan fish is feared to cause population extinction in nature.

Seeing the condition of Klawing River and considering the importance of senggaringan fish as resources, it is necessary to conduct a study on the status and management of senggaringan fish in the Klawing River. This study is expected to help the course of senggaringan fish management and conservation and its sustainable consumption in the future.

\section{METHODS OF RESEARCH}

This research was conducted in Purbalingga District, Central Java Province, Indonesia. The focus of the research study is the Klawing river area which is administratively included in the districts of Purbalingga.

This research was conducted using qualitative methods and the data were obtained through literature study, field observation, and in-depth interview. In-depth interview employed open questionnaires to informants who master the issue in the management of aquatic and fish resources in the Klawing River. Contributing stakeholders were still limited to the Fisheries and Food Security Agency of Purbalingga District and river users including fishermen, fishing communities, sand and stone miners, and community leaders.

The main components in the open questionnaire included (1) legal or regulatory system implemented in resources management; (2) business systems and resources utilization; (3) conservation efforts and activities: (4) local wisdom; (5) management model and (6) conflicts of interest.

\section{RESULTS AND DISCUSSION}

Study on senggaringan fish has been conducted both in terms of ecology, habitat, eating habits, genetics, and reproduction. Senggaringan fish generally live in slow-flowing rivers $(0.08-0.16 \mathrm{~m} / \mathrm{s})$, in the bottom of shallow waters or deep waters. The basic substrate is usually a mixture of sand, gravel, and rocks, sometimes overgrown with moss (Sulistyo and Setijanto 2002). Heltonika (2009) has reported that there is a close relationship between the composition of food types and the level of gonadal maturity. For reproduction process in nature, senggaringan fish tend to choose foods such as Gastropod because it contains cholesterol, although the amount of cholesterol is unknown. Energy deposits for gonadal maturation are stored in several organs, such as dorsal muscles, adiphose fin, liver, and viscera. Senggaringan fish experience gonadal maturation for the first time when their size reaches $14.89 \mathrm{~cm}$.

Pramono (2010) has also made a report on the reproductive profile of senggaringan fish for one year in which there were four peak values of the Gonad Somatic Index (GSI) in January, July, August, and November. The potential of ovum to be ovulated in July and August was marked by an increase in reproductive hormones. Taxonomic confirmation has been conducted by Pramono et al., (2017) as well. Scientific name of senggaringan fish, which was used to be Mystus nigriceps, now becomes Mystus singaringan (Figure 1). The result of preliminary research on genetics have showed that senggaringan fish in the Klawing River have no polymorphism or in other words, have low diversity (Pramono et al., 2018). The absence of genetic diversity is thought to affect the stability of the population. 


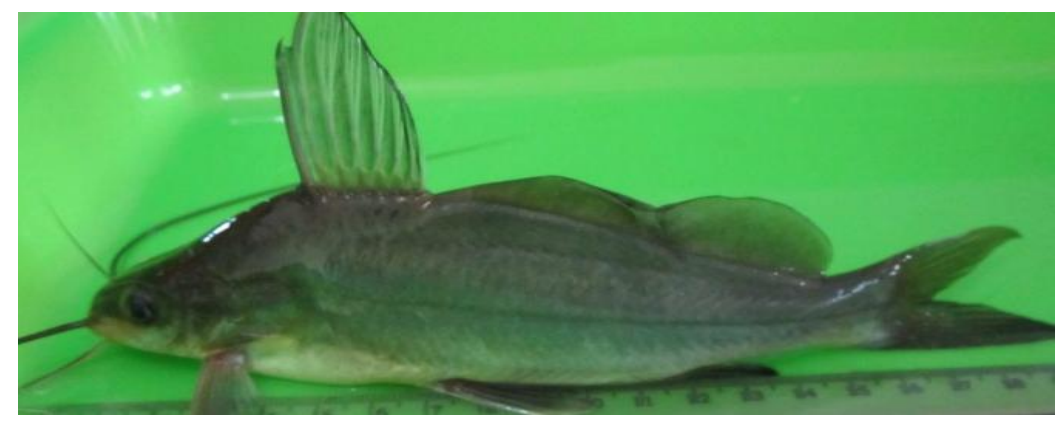

Figure 1 - Senggaringan fish (Mystus singaringan) from the Klawing River

The legal and regulatory instruments and other instructions implemented by the Fisheries and Food Security Agency of Purbalingga Regency in the management of natural resources both in waters and fisheries are:

- Law Number 4 of 1982 concerning Basic Provisions for the Management of the Living Environment;

- Law Number 5 of 1990 concerning Conservation of Natural Resources and Ecosystems;

- Law Number 31 of 2004 concerning Fisheries;

- Republic of Indonesia Government Regulation Number 29 of 1986 concerning Analysis of Environmental Impacts;

- Instruction of The Governor of Central Java No 523/173/1986 dated to May 26, 1986 regarding Prevention/Prohibition of Businesses/Actions that result in Pollution/Damage to Fish Resources in Public or Marine Waters in Central Java Province;

- Instruction of The Regent of Purbalingga No 523-575/1993 dated to October 19, 1993 concerning Prevention/Prohibition of Businesses/Actions that result in Pollution/Damage to Fish Resources in Public Waters in Purbalingga District.

Table 1 - Excerpts of Resources Management Laws and Regulations

\begin{tabular}{|c|c|}
\hline $\begin{array}{l}\text { Laws and Regulations } \\
\text { Implemented }\end{array}$ & Excerpts \\
\hline $\begin{array}{l}\text { Chapter XV Article } 84 \\
\text { paragraph } 1 \text { of Law } \\
\text { Number } 31 \text { of } 2004\end{array}$ & $\begin{array}{l}\text { A person who intentionally catches and/or cultivates fish in the fisheries area of the } \\
\text { Republic of Indonesia by using chemicals, biological materials, explosives, tools and/or } \\
\text { [their] environment as referred to in article } 8 \text { paragraph } 1 \text {, shall be sentenced to } \\
\text { imprisonment not to exceed } 6 \text { (six) years and a fine not to exceed Rp. } 1,200,000,000 \\
\text { (one billion two hundred million rupiahs) }\end{array}$ \\
\hline $\begin{array}{l}\text { Chapter VII Article } 22 \\
\text { of Law Number } 4 \text { of } \\
1982\end{array}$ & $\begin{array}{l}\text { Anyone who intentionally commits an act that causes damage to the environment which } \\
\text { is regulated in this Law or other Law, may be imprisoned for a term not exceeding } 10 \\
\text { (ten) years and/or fined not exceeding Rp. 100,000,000 (one hundred million rupiahs) } \\
\text { (Paragraph 1). } \\
\text { Whosoever, because of negligence, commits an act which causes damage to the } \\
\text { environment which is regulated in this Law or other Law, shall be punished by } \\
\text { imprisonment not exceeding } 1 \text { (one) year and/or a fine not exceeding Rp. 1,000,000 } \\
\text { (one million rupiahs) (Paragraph 2) }\end{array}$ \\
\hline $\begin{array}{l}\text { Chapter VII Article } 27 \\
\text { of Law Number } 4 \text { of } \\
1982\end{array}$ & $\begin{array}{l}\text { Whosoever violates the provisions stipulated in the article } 4 \text { (Fish Resources } \\
\text { Management) shall be punished by a fine not to exceed Rp. 25,000,000 (twenty-five } \\
\text { million rupiahs) (Paragraph 1). } \\
\text { Whosoever violates the provisions stipulated in the article } 20 \text { (Prohibition of Exports and } \\
\text { Imports of Fish Species) shall be punished by a fine not to exceed Rp. 5,000,000 (five } \\
\text { million rupiahs). (Paragraph 2). }\end{array}$ \\
\hline
\end{tabular}

The implementation of laws and regulations relating to the utilization of the aquatic environment, natural resources, and fish resources has been persuasively introduced to the public. In the laws and regulations implemented, there are clearly punishments, sanctions, or criminal provisions for proven actions. Table 1 is list of excerpts of punishments / sanctions/criminal provisions in the laws and regulations implemented. 
Commercial fishing is run by fishermen on their own, either using fish traps, fishing rods, or cast nets. The fish caught are sold to collectors or restaurants that provide specific menus for freshwater fish and sold to other parties or markets in ready-to-eat form. The price of fish varies. For cyprinid fish or fish from the Cyprinidae family, the price ranges from Rp. $20,000-25,000 / \mathrm{kg}$. The price of baung fish (Mystus nemurus) and senggaringan fish from Bagridae family ranges from Rp. 30,000 to 40,000 / Kg.

Other commercial activities that utilize the Klawing River are sand and stone mining. Sand and stone miners are companies or individuals who have obtained mining permits from relevant agencies for 3 years. However, there are also illegal mining activities. On average, one village on the riverbank of the Klawing River has 2 to 5 mining mines. Many fishermen change profession as sand miner. The mining itself is run traditionally. Sand is taken from the Klawing River in a boat ( $\pm 4 \mathrm{~m} 3)$ and sold for Rp. 80,000 to the depot on the riverbank of the Klawing River.

Conservation efforts that have been made by Fisheries and Food Security Agency regarding the use of aquatic and fish resources are campaign to community, especially fishermen community, by holding activities to foster management of capture fisheries. The campaign provided includes the prohibition on the use of explosive devices, chemical and electrical shock, and the use of other fishing gears that may endanger the conservation of biological resources in public waters. Fisheries and Food Security Agency also campaigns for laws and regulations related to the utilization of aquatic and fish resources. In addition, the community is also given an understanding of damage and pollution of the environment of fish resources.

The damage of the environment of fish resources is an environmental condition of fish resources in a particular water body that has undergone physical, chemical and biological changes, so that it does not function as a place to live, forage, breed, or shelter for fish resources, because it has experienced interference in such a way as a result of the actions of a person or legal entity. Meanwhile, environmental pollution of fish resources is emphasized on the penetration or inclusion of living things, substances, energy and/or other components into the environment of fish resources so that the environmental quality of fish resources declines to a certain level and causes the environment of fish resources to be unable to function according to its designation.

Another effort by Fisheries and Food Security Agency is to restock fish in the river with fish from cultivation. The types of fish restocked into the rivers are bonylip barb, silver barb, and tilapia. Restocking activities is funded by the Agency of Marine and Fisheries of Central Java Province.

Local people usually catch fish according to seasonality calendar and wetonan cycle, a cycle which superimposes the five-day pasaran cycle in the Javanese calendar with the seven-day week cycle in the Gregorian calendar. The fishermen already know that the first seasonality in the Javanese calendar, or from July to August, is the spawning season. During those times, almost all fish, including senggaringan fish, spawn. Fishermen will not catch fish on Selasa (Tuesday) Kliwon and Jumat (Friday) Kliwon. Other local wisdom is the annual the Klawing Festival, held in Kedungbenda Village in the downstream before the meeting point of Klawing River and Serayu River. The activity during the festival is to do larung perahu, in which all households of Kedungbenda Village donate one ketupat (rice cake) and a small bag of fish from the catch in the Klawing River to eat together and to be served to visitors.

Management model developed by the Fisheries and Food Security Agency is to form Kelompok Pengawas Masyarakat (Pokwasmas) or Community-based Supervisory Group. This supervisory group is actually a group of fishermen in each village along the Klawing River. There were 31 supervisory groups listed. The model developed is co-management (joint management) where supervisory groups are given trust in maintaining, utilizing, and managing waters. The Fisheries and Food Security Agency also grants supervisory groups business capital assistance in the form of boats and cast nets.

The supervisory groups are asked to monitor and report the events or practices of environmental destruction and illegal fishing. The level of participation of supervisory groups is relatively high. The occurrence of deaths of several types of fish in the Klawing River have 
been once reported to the Fisheries and Food Security Agency. At first the fish swam down slowly, then they floated in the waters. The supervisory groups suspect that there is waste pollution in the river, because if it is due to fishing activity with poisons, the fish will not show such symptoms. Unfortunately, the report has not been followed up by the agency. This is understandable as supervisory groups know about limited cross-sectoral scope and intersectoral conflicts of interest within the regional government.

Cross-sectoral conflicts of interest occur within regional and central government agencies. The construction of the Slinga dam in the central part of the Klawing River to irrigate paddy fields, which was funded by state budget, resulted in habitat fragmentation. This habitat fragmentation will inevitably prevent fish from looking for food and affect the distribution, reproductive behavior, and colonization of various fish species. In long term, it will accelerate the extinction of the remaining species.

The value system developed in the management of fish resources in the Klawing River includes 3 aspects:

- Economic Value. Conservation of fish resources is expected to practically provide many possible economic values that can be realized as income for fishermen and the fulfillment of sustainable sources of protein;

- Educational Value. Conservation of fish resources can provide future generations an access to learn more about biodiversity, ecosystems, and aquatic biota communities;

- Scientific Value. Public water ecosystems that are maintained are expected to be utilized for scientific research and other scientific purpose in the future. The results of scientific research are expected to provide ecological guidance that can be used as a basis for policy in environmental management.

\section{DISCUSSION OF RESULTS}

Statistically, the status and potential of senggaringan fish are relatively large, reaching 98.56 tons in 2012-2016 period. Based on primary observation, the abundance of senggaringan fish is very low and according to the fishermen, senggaringan fish have also begun to be rarely caught. Suryaningsih et al. (2018) have caught 5 senggaringan fish in the middle part of the Klawing River and 7 senggaringan fish in the lower part. The research result of Pramono et al. (2018) has showed that senggaringan fish have no polymorphism or genetic diversity. This is suspected to affect the stability of its population in the Klawing River.

In general, legal protection for the management of fish and water resources is adequate. However, those legal protections, such as Law Number 45 of 2009 concerning amendments to Law Number 31 of 2004 and Government Regulation Number 60 of 2007 concerning Conservation of Fish Resources, lack renewal. The management of aquatic and fish resources is no longer centralized in the central government, but has been decentralized as an obligation for regional or municipal government, although the latest local regulations and regulatory systems that characterize decentralized sustainable management are still not perceptible. The implementation of the laws and regional regulations of Purbalingga Regency, especially at institutions or agencies that support the management of aquatic and fish resources, still needs to be studied scientifically.

Excavation type $\mathrm{C}$ mining, which is sand and stone mining, is increasingly damaging senggaringan fish habitat in the Klawing River because senggaringan fish are very fond of shallow or deep water habitat protected by sand, gravel, and rocks as basic substrates. Sand and stone mining activities also occur in the Kampar River in Riau (Fithra and Siregar, 2010) and the Kelingi River in Lubuklinggau (Samitra and Rozi, 2018). Indeed, type C mining activities change and decrease fish diversity. This is evident in the Kampar River in Riau, in which there were 160 species of fish in 1995, but then the number of species reduced by $52 \%$ and left only 83 species in 2003 (Agency of Marine and Fisheries of Riau Province, 2003). Economic valuations due to damage to resources is likely need to be done. Damage to aquatic resources does not only cause the extinction of a population but also results in the loss of sources of protein and community income (Wargasasmita, 2005). 
Conservation of fish resources through restocking has been relatively good to increase fish production in the Klawing River. However, restocking actually contradicts the Regulation of the Minister of Maritime Affairs and Fisheries Number 41 of 2014. The contradiction lays on types of tilapia which are stocked in the waters. The Regulation of the Minister of Maritime Affairs and Fisheries Number 41 of 2014 states that tilapias (Oreochromis niloticus, $O$. mossambicus) are invasive alien species. The categorization of tilapia as invasive alien species has been also stated earlier by Wargasasmita (2005), Rachmatika, and Wahyudewantoro (2006). Wargasasmita has stressed that the increase in fish production in a water body is very much determined by the productivity of the waters, not by the introduction of alien fish. Purwono (2001) has reported that article $8 \mathrm{f}$ of biodiversity convention states that each country is obliged to avoid the introduction of invasive alien species which will cause environmental impacts and damage to the biodiversity of native species.

The presence of tilapia which is stocked in the waters has the potential to impact native fish species in the Klawing River in term of space, food, and others. Sentosa et al. (2013) have reported a risk potential assessment of tilapia stocked in Lake Beratan in Bali which reached a value of 13 from a maximum value of 16 . The impact of risk reached a value of 41 from a maximum value of 61 and ecological risk reached a value of 54 from a maximum value of 77 . Wargasasmita (2005) has stated that the greatest risk is feeding and habitat competition between native fish species and introduced fish species. However, in general, any type of fish that is introduced into public waters has significant ecological value. The thing that sets it apart is the level of risk. Sentosa and Wijaya (2013) have also emphasized that the introduction of fish should not be carried out without prior research concerning the potential impact of the introduction of fish on native fish in an aquatic area. Some of the factors that cause declining diversity and communities of fish in public waters include habitat change, over-exploitation, introduction of invasive alien species, pollution, competition for water use, and global warming (Dudgeon, 2000).

The local wisdom of the fishermen is relatively good. They do not catch fish during the spawning season and it is really a wise practice from the fishermen. Other forms of local wisdom that can help the fishermen to catch fish with certain size may need to be initiated. This is because small fish, which are called ikan lembutan by local people, are often unintentionally caught while catching certain target species and target sizes of fish.

The development of the co-management of aquatic and fish resources in the Klawing River which was initially instructive from the local government has now developed into a community-based participation in the form of the Community-based Supervisory Group. Comanagement between the beneficiary community and the Fisheries and Food Security Agency in the case of Klawing River is still far from the concept, practice and sustainability, because there is still an imbalance in the role distribution. On the one hand, the community has been active in supervising and reporting the death of large number of fish, but on the other hand the, the Fisheries and Food Security Agency of Purbalingga Regency has not been able to follow up the report. This is because there is still a conflict of interest between the Fisheries and Food Security Agency and other agencies and the private sector in the utilization of resources.

The implementation of co-management must be extended to the participation of other stakeholders (Partomo et al., 2011). Nasution et al. (2014) have stated that in developing a co-management system for fish resources, it is necessary to involve broader stakeholders, such as central government, local governments, companies, and fishing communities. Borrini-Feyerabend et. Al. (2000) have defined co-management as a situation where more than one party negotiates to define and guarantee the distribution of roles between them in managing and take responsibilities for an area or system of resources.

\section{CONCLUSION AND RECOMMENDATIONS}

The population of $M$. singaringan fish has declined. However, they have the potential to be domesticated in the context of restocking and conservation. Resource management 
of $M$. singaringan in Klawing River needs to involve stakeholders according to their level of importance and influence.

\section{ACKNOWLEDGEMENTS}

We would like to thank the Ministry of Research, Technology and Higher Education of the Republic of Indonesia for the scholarship support.

\section{REFERENCES}

1. Akhter, S., Akhter, M. \& Hossain, M. (2017). Length-weight relationship and condition factor of two Gangetic Mystus species, Mystus tengra (Hamilton, 1822) and Mystus cavasius (Hamilton, 1822). Journal of Entomology and Zoology Studies, 5(2), 979-982.

2. Ammar, J. A., M. M. Kamal. Dan Sulistiono. 2014. Fish Diversity in Calam Lake, Musi Banyuasin District, South Sumatera. Depik 3 (3): 216-220.

3. Bahiyah., D.D. Solihin., dan R. Affandi. 2013. Genetic variation pf population barb (Barbonymus balleroides, Val. 1842) as habitat fragmentation impact in Serayu River. Jurnal Iktiologi Indonesia 13 (2): 175-186.

4. Borrini-Feyerabend, G., Farvar, M.T., Nguinguiri, J.C., Ndangang, V.A. 2000. CoManagement of Natural Reosurces: Organizing, Negotiating and Leranig by-Doing. Heidelberg. Germany. GTZ and IUCN, Kasparek Verlag.

5. Dudgeon, D. 2000. The ecology of tropical asian rivers and stream in relation to biodiversity conservation. Annu. REV. Ecol. Syst. 31: 239-263.

6. Fithra, R. Y., dan Siregar, Y. I. 2010. Fish diversity In Kampar River: Inventaritation from Kampar Kanan River. Enviromental Science Journal 2 (4): 139-147. [In Indonesian]

7. Garg, R.K., N. Batav and R.K. Singh. 2013. Identification of genetic polymorphism in Mystus cavasius (Hamilton-Buchanan, 1822) from Gandhisagar reservoir and Bansagar reservoir, Madhya Pradesh, India. Journal of Basic and Applied Zoology 66: 93-100.

8. Gunawan, E. H. Dan Jumadi. 2016. Diversity of fish and mapping distribution of invasive banned and. protected fish at Rawadanau concervation Banten Area. Fisheries and Fisheries and Marine Journal 6 (1): 67-73. [In Indonesian].

9. Heltonika, B. 2009. Food study and relationship with reproduction of Senggaringan fish (Mystus nigriceps) in Klawing river Purbalingga, Central Java. Thesis. Bogor Agricultural University. Bogor. Indonesia. [In Indonesian].

10. Naeem, M., \& Ishtiaq, A. (2011). Proximate composition of Mystus bleekeri in relation to body size and condition factor froma Nala Daik, Sialkot, Pakistan. African Journal of Biotechnology, 10(52), 10765-10773. https://doi.org/10.5897/AJB10.2339.

11. Naeem, M., Zuberi, A., Hasan, Z., Salam, A., Khan, M., Ayaz, M.M., Ishtiaq, A. (2012). Length-weight and length-length relationship of freshwater wild catfish Mystus bleekeri from Nala Daik, Siakiot, Pakistan. African Journal of Biotechnology, 11(50), 1116811172. https://doi.org/10.5897/AJB12.958.

12. Nasution, S. H., Lukman.m Sulastri., Koeshendrajana, Ridwansyah, I., Sugiarti., Nafisyah, E. 2014. Directions for Management and Conservation of Fish Resources in Lake Towuti, South Sulawesi. Proceedings of the Presentation of Research Results of the 2014 LIPI Geotechnology Research Center. 615-631 p.

13. Partomo, Mangkuprawira, S., Hubeis, A.V.S., Adrianto. 2011. Lake Management Based Co-Management: Rawa Pening Case. 2011. JPSL 1 (2): 106-113. [In Indonesian]

14. Regulation of the Minister of Maritime Affairs and Fisheries of the Republic of Indonesia Number 41 of 2014. Prohibition of Importing Dangerous Fish Species from Overseas into the Territory of the Republic of Indonesia. Ministry of Maritime Affairs and Fisheries of the Republic of Indonesia.

15. Pramono T. B. 2010. Rerproduction profile of Senggaringan fish (Mystus nigriceps): Basis Domestication and cultivation develepment. Thesis. Bogor Agriculture University. Bogor.[In Indonesian].

16. Pramono, T.B,, Arfiati, D., Widodo, M.S., Yanuhar, U. 2017. Identification of Mystus with 
genetic approach. Sumberdaya Akuatik Indopasifik Journal. 1(2):1-9.

17. Purwono, B. 2001. Biodiversity Management Policy. National Workshop I: Integrated Biodiverssity Strategy and Action Plan. Bappenas. Hotel Salak, Bogor 6-7 November 2001.

18. Rachmatika, I., dan G. Wahyudewantoro. 2006. Introduced Fishes to Inland Waters in West Java and Banten: Some Notes on its Taxonomic and Distribution. Iktiologi Indonesian Journal 6 (2): 93-97. [In Indonesian].

19. Sentosa, A. A., D. Wijaya, dan D. W. H. Tjahjo. 2013. Risk Assessment of Introducing Fishes in Lake Beratan, Bali. Proceedings of the National Forum for Recovery and FishIV Resource Conservation. Research Institute for Recovery and Fish Resource Conservation. Marine and Fisheries Ministry. Purwakarta. West Java.

20. Sukamsiputro, S. 2002. Ecology of Baceman Fish (Mystus nemurus) on the Klawing River in Purbalingga Regency and Several Factors Relating to Domestication. Thesis. Post Gradute Program, Jenderal Soedirman University, Purwokerto.[In Indonesian].

21. Sulistyo, I. Dan Setijanto. 2002. Ecology and reproduction aspect of Senggaringan fish (Mystus nigriceps): Basis Domestication and cultivation. Research report. Faculty of Biology, Jenderal Soedirman University. [In Indonesian]

22. Suryaningsih, S., M. Sagi., K. H. Nitimulyo., and S. Hadisusanto. 2012. Spawning aspects of javaean barb Puntius orphoides (Valenciennes, 1842) in Klawing River, Purbalingga, Central Java. Jurnal Iktiologi Indonesia 12 (1): 35-48.

23. Wahyudewantoro, G. 2010. Study of potential fish in the Tasik Betung peatland, Riau. Bionatura-Journal of Physical and Physical Sciences, 12 (2): 57-62.

24. Wargasasmita. S. 2005. Invasion threat of exotic fish species to diversity of indigenous fish species. Jurnal Iktiologi Indonesia Journal 5 (1): 5-10. 